\title{
Impact of Direct Acting Antiviral Agents on Psychiatric and Sexual Health of Patients with Hepatitis C Virus
}

\author{
Direkt Etkili Antiviral Ilaçların Hepatit C Hastalarının Psikiyatrik ve Cinsel Sağlıkları \\ Üzerine Etkileri
}

\author{
(1) Özlem Kuman Tunçel1 ${ }^{1}$, (D Deniz Akyol2 (1) Hüsnü Pullukçu², (1) Tansu Yamazhan², \\ (1) Meltem Işıkgöz Taşbakan², (1) Özen Önen Sertöz¹
}

${ }^{1}$ Ege University Faculty of Medicine, Department of Psychiatry, Izmir, Turkey

2Ege University Faculty of Medicine, Department of Infectious Diseases and Clinical Microbiology, Izmir, Turkey

\section{ABSTRACT}

Objectives: Data about the psychosocial side effects of directacting antiviral agents (DAA) used for the treatment of hepatitis $C$ virus (HCV) infection is scarce. In this study, it is aimed to assess the psychiatric and sexual effects of ledipasvir/sofosbuvir (L/S) combination and paritaprevir-ritonavir-ombitasvir-dasabuvir (PROD) combination in patients with HCV infection.

Materials and Methods: The sample of this retrospective study consisted of patients who were diagnosed with HCV infection and received PROD or L/S treatment. The patients were assessed by the Hospital Anxiety and Depression (HAD) scale and Arizona Sexual Experiences (ASEX) scale at baseline and first-, third- and sixth-month visits. Besides these, demographic data and data about the liver disease were collected.

Results: During the studied period, 42 patients were started DAA treatment. The average age of the sample was $56.64 \pm 12.04$ years. Thirty-five (83.3\%) patients achieved sustained viral response. Data of the patients who filled HAD or ASEX at baseline and at least in one of the following visits within six months were used. Anxiety, depression and sexual measures did not differ between baseline and following assessments.

Conclusion: L/S and PROD do not seem to have a significant effect on anxiety and depression levels and sexual experiences of the patients while they made an improvement in viral load.

Keywords: Anxiety, sexual dysfunction, depression, direct acting antiviral agents, hepatitis $\mathrm{C}$ virus, adverse effects
ÖZ

Amaç: Hepatit C tedavisinde kullanılan direkt etkili antiviral ajanların (DAA) psikososyal yan etkileri ile ilgili veri çok sınırlıdır. Bu çalışmada ledipasvir/sofosbuvir (L/S) kombinasyonu ile paritaprevir-ritonavirombitasvir-dasabuvir (PROD) kombinasyonunun hepatit $\mathrm{C}$ virüsü $(\mathrm{HCV})$ ile enfekte hastalardaki psikiyatrik ve cinsel etkilerinin araştııııması amaçlanmıştır.

Gereç ve Yöntemler: Bu retrospektif çalışmanın örneklemini HCV enfeksiyonu tanısı konan ve PROD ya da L/S tedavisi görmüş olan hastalar oluşturmaktadır. Hastalar tedavi öncesi ilk vizit ile birinci, üçüncü ve altıncı aylardaki vizitlerde Hastane Anksiyete Depresyon (HAD) ölçeği ve Arizona Cinsel Yaşantılar (ACYÖ) ölçeği ile değerlendirilmişlerdir. Bunların yanı sıra hastaların demografik ve karaciğer hastalığı ile ilgili verileri de çalıșmada kullanıımıștır.

Bulgular: Çalışma dönemi sürecinde 42 hastaya DAA başlanmıştır. Örneklemin ortalama yaşı 56,64 $\pm 12,04$ 'tür. Hastaların 35'inde $(\% 83,3)$ kalıcı viral yanıt sağlanabilmiştir. Bazı hastaların ölçekleri tam olarak doldurmaması nedeniyle bazal ve takip eden altı ay içindeki en az bir vizitte HAD ya da ACYÖ'yü dolduran hastaların verileri kullanıımıştır. Anksiyete, depresyon ve cinsel yaşantı ile ilgili ölçümler açısından bazal ve izlemdeki değerlendirmeler arasında bir farklıık saptanmamıştır.

Sonuç: L/S ve PROD tedavileri viral yük açısından iyileşme sağlarken, anksiyete ve depresyon düzeyleri ile cinsel yaşantı üzerinde belirgin bir etki göstermemiştir.

Anahtar Kelimeler: Anksiyete, cinsel disfonksiyon, depresyon, direkt etkili antiviral ilaçlar, hepatit $\mathrm{C}$ virüsü, istenmeyen etkiler

Kuman Tunçel Ö, Akyol D, Pullukçu H, Yamazhan T, Işıkgöz Taşbakan M, Önen Sertöz Ö. Impact of Direct Acting Antiviral Agents on Mental and Sexual Health of Patients with Hepatitis C Virus. 2019;25:25-31.

Address for Correspondence: Özlem Kuman Tunçel MD, Ege University Faculty of Medicine, Department of Psychiatry, Izmir, Turkey Phone: +90 2323903430 E-mail: kumanozlem@yahoo.com ORCID ID: orcid.org/0000-0002-9632-6173 Received: 21.01.2019 Accepted: 03.03.2019

${ }^{\odot}$ Copyright 2019 by Viral Hepatitis Society / Viral Hepatitis Journal published by Galenos Publishing House. 


\section{Introduction}

Hepatitis $\mathrm{C}$ virus (HCV) infection is one of the leading causes of chronic liver disease and there are approximately 71 million chronically infected individuals globally $(1,2)$. The prevalence of $\mathrm{HCV}$ infection varies from country to country. For Turkey, findings of Tozun et al. (3) revealed anti-HCV positivity in $1 \%$ of the adult population. Genotype 1b is the most common HCV genotype in Turkey $(4,5,6,7)$.

Hepatitis C treatment showed significant changes over the years. Sustained viral response (SVR) rates of up to $99 \%$ have been reported with combinations of direct-acting antivirals (DAAs) $(8,9)$. The use of sofosbuvir/ledipasvir (S/L) and paritaprevir-ritonavirombitasvir-dasabuvir (PROD) combinations was approved by the FDA in 2014 (10) and reimbursement started in 2016 in our country (11).

Interferon treatment has many psychiatric side effects such as irritability, anger, anxiety, emotional instability, fatigue, sleep disturbances and severe depression $(12,13,14)$. DAAs are assumed to provide higher cure rates with fewer side effects. The most common reported side effects for L/S are fatigue, headache and nausea (9), and for PROD are insomnia, rash, redness of the skin, itchy skin, swollen throat, face, tongue, lips, hands, feet, ankles, or lower legs, weakness, and confusion (15). In ION and PEARL studies which establish safety and efficacy for L/S and PROD respectively, no psychiatric serious adverse events were reported $(9,16,17)$. Insomnia and irritability were among the common adverse events for both. In a recent study, anxiety (7.1\%), depression (12.6\%) and insomnia/sleep disorders (14\%) were reported among the DAArelated adverse events (18). The rate of psychiatric disorders in the DAA group was identical to those observed in the placebo group in that study. In most of the clinical trials of DAAs, anxiety, depression or sexual side effects were not specifically focused. Sundberg et al. (19) published the first study that monitored psychiatric adverse effects of daclatasvir, sofosbuvir and simeprevir in a sample of 17 patients. They found that DAA treatment did not increase depressive symptoms or sleep disturbance with a high SVR of $88 \%$. Gallach et al. (20) evaluated anxiety and depression status of 145 DAA-treated patients by Hospital Anxiety and Depression scale (HADS) (21) in their prospective study. They reported that anxiety and depression scores did not change during the follow-up period (treatment period and 12 weeks after). In a study sample of veterans with and without mental health diagnosis, there was no change in depression scores evaluated by the Patient Health Questionnaire, from baseline to end of the treatment (22). No psychiatric decompensation was reported while using DAA in that study.

For sexual side effects, Lenz et al. (23) reported a case of acute onset sexual dysfunction within the first month of the $\mathrm{S} / \mathrm{L}$ treatment. Besides, it is known that HCV infection is strongly associated with sexual health issues. Karaivazoglou et al. (24) defined three patterns of sexual dysfunction in HCV-infected patients: pre-cirrhotic sexual impairment, cirrhosis-induced sexual decline and interferon-associated sexual difficulties.

Considering the paucity of studies in the field of psychiatric effects of DAA, we planned our study. We aimed to evaluate the psychiatric and sexual effects of $S / L$ and PROD combinations that have recently been used in patients with chronic $\mathrm{HCV}$ infection.

\section{Materials and Methods}

This retrospective study was performed by the collaboration of the Ege University Hospital, Clinic of Infectious Diseases and Clinical Microbiology and Clinic of Psychiatry. The sample consisted of patients who were diagnosed with $\mathrm{HCV}$ infection and received PROD or L/S treatment. The physicians had decided to initiate DAA treatment in accordance with the guidelines. The duration of treatment was 12 weeks for PROD and, 12 or 24 weeks for L/S treatment depending on viral genotype and fibrosis stage. For this study, a negative test for HCV RNA at 12 weeks post-treatment was defined as SVR.

During their DAA treatment, anxiety and depression level of the patients was assessed by HADS (21). Besides, sexual side effects were evaluated by the Arizona Sexual Experiences scale (ASEX) (25). The patients filled the questionnaires at the baseline and first-, third- and sixth-month visits. In the adaptation and reliability studies of these scales for the Turkish population, 7 was found to be the cut-off score for depression subscale and 10 was found to be the cut-off score for anxiety subscale of the HADS (26); and 10 for the ASEX (27). Scores higher than these cut-off points were defined as depression risk, anxiety disorder risk and sexual dysfunction.

In this retrospective study, PROD or L/S treated patients' demographic data, anxiety and depression scores, sexual experience scores and data about HCV infection were collected. Patients gave consent to the use of their data. We have obtained approval for the study from the Infectious Diseases and Clinical Microbiology Department of Ege University.

\section{Statistical Analysis}

Data analyses were performed by IBM SPSS, version 21.0, for Windows. The Shapiro-Wilk test was used to analyze normality. Quantitative data were presented as mean and standard deviations if there is a normal distribution, as median and interquartile ranges if there is skewed distribution. To compare the paired data; for analysis of quantitative data, the paired sample t-test was used for the data with normal distribution, the Wilcoxon signed-rank test was used for the data with skewed distribution and for comparison of qualitative data, McNemar's test was used. An alpha level of 0.05 was set up to indicate statistical significance.

\section{Results}

During the study period, 42 patients were started DAA treatment (Figure 1). The average age of the sample was $56.64 \pm 12.04$ years. Twenty-five $(53.2 \%)$ of them were female. In the study sample, genotype $1 \mathrm{~b}$ was present in 36 (85.7\%) patients, genotype 1a in three, genotype 4 in two (4.8\%) patients and, one patient had genotype 1 $(2.4 \%)$, however, subclassification was not performed. Nine $(21.4 \%)$ patients had cirrhosis. Twenty (47.6\%) patients were previously treated with another treatment regimen, and 19 (45.2\%) were treated with an interferon-based treatment. Viral load declined to 0 in all patients during the treatment period. Thirty-five (83.3\%) patients achieved SVR, one $(2.4 \%)$ patient was reinfected by another genotype and data of six (14.3\%) patients about SVR are missing.

There was no significant correlation between baseline viral load and baseline depression, anxiety and ASEX scores. Most of the patients had not filled in the questionnaires completely. The flowchart of the patients is provided in Figure 1. Among 42 


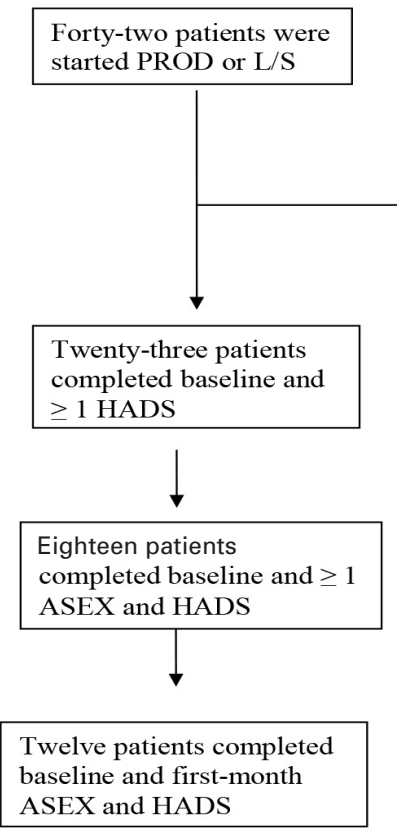

Figure 1. Flowchart of the study

ASEX: Arizona Sexual Experiences scale, HADS: Hospital Anxiety and Depression scale, L/S: Ledipasvir-sofosbuvir combination, PROD: Paritaprevir-ritonavirombitasvir-dasabuvir combination patients, who were started PROD or L/S, 23 patients completed HADS questionnaire at baseline and at least in one of the following visits within six months. Among these 23 patients, four (36.4\%) patients using PROD and seven (55.6\%) patients using L/S were female. The average age of PROD group was 53.55 \pm 10.11 and of L/S group was $59.17 \pm 11.91$ years. Comparison of their baseline scores with the following highest scores for HADS is given in Table 1. There was no significant difference in anxiety and depression scores between females and males at any time. No correlation was detected between age and depression or anxiety scores during follow-up. As the number of the patients, who were at risk for depression or anxiety disorder, was very low for each treatment group, the comparison between baseline and following visit results of these variables are made for the whole group (Table 1).

Eight patients using PROD and nine patients using L/S filled the HADS both at the beginning of the treatment and at the first month. Among these 17 patients; three (37.5\%) patients using PROD and five (55.6\%) patients using L/S were female. The average age of PROD group was $54.63 \pm 10.11$ and of L/S group was $61.67 \pm 9.45$ years. There was no significant difference between baseline and the first-month visit HADS scores while there was a significant decrement in the viral load (Table 2). As the number of patients, who were at risk for depression or anxiety disorder, was very low for each treatment group, the comparison between baseline and first-month results for these variables were made for the whole group.

Table 1. Comparison of the baseline measurements with the follow-up measurements on the basis of the Hospital Anxiety and Depression scale

\begin{tabular}{|c|c|c|c|c|c|}
\hline \multirow{2}{*}{ Variable } & \multicolumn{2}{|l|}{ Baseline } & \multicolumn{3}{|c|}{ Follow-up } \\
\hline & n & $\%$ & \multicolumn{2}{|l|}{$\mathrm{n}$} & $\%$ \\
\hline At risk for depression in PROD & 0 & 0 & \multicolumn{2}{|l|}{1} & 8.3 \\
\hline At risk for depression in L/S & 1 & 8.3 & \multicolumn{2}{|l|}{5} & 41.7 \\
\hline At risk for anxiety disorder in PROD & 5 & 45.5 & \multicolumn{2}{|l|}{4} & 36.4 \\
\hline \multirow[t]{2}{*}{ At risk for anxiety disorder in L/S } & 7 & 58.3 & \multicolumn{2}{|l|}{5} & 41.7 \\
\hline & $\mathbf{n}$ & $\%$ & $\mathbf{n}$ & $\%$ & Statistics \\
\hline At risk for anxiety disorder $(n=23)$ & 12 & 52.2 & 9 & 39.1 & $p=0.375$ \\
\hline \multirow[t]{2}{*}{ At risk for depression $(n=23)$} & 1 & 4.3 & 6 & 26.1 & $p=0.063$ \\
\hline & Mean & SD & Mean & SD & \\
\hline HADS-A for PROD & 5.64 & 4.23 & 5.73 & 3.82 & $\begin{array}{l}T=-0.102, \\
p=0.921\end{array}$ \\
\hline HADS-A for L/S & 7 & 4.31 & 6.58 & 4.17 & $\begin{array}{l}\mathrm{T}=0.422 \\
\mathrm{p}=0.681\end{array}$ \\
\hline HADS-D for PROD & 5 & 3 & 5.27 & 3.66 & $\begin{array}{l}T=-0.346 \\
p=0.736\end{array}$ \\
\hline HADS-D for L/S & 5.42 & 4.62 & 7.58 & 5.66 & $\begin{array}{l}T=-2.106, \\
p=0.059\end{array}$ \\
\hline Viral load for PROD* (IU/mL) & 368656.27 & 714263.58 & 0 & 0 & $\begin{array}{l}Z=-2.366 \\
p=0.018\end{array}$ \\
\hline Viral load for L/S (IU/mL) & 1684255.33 & 1504357.84 & 0 & 0 & $\begin{array}{l}T=3.878 \\
p=0.003\end{array}$ \\
\hline \multicolumn{6}{|c|}{$\begin{array}{l}\text { The lowest viral load achieved, and the highest HADS-A and HADS-D scores within six months were used for follow-up measurements. PROD group consists of } 11 \text {, } \\
\text { L/S group consists of } 12 \text { patients. } \\
\text { *Viral load for PROD had a skewed distribution. The median values and interquartile ranges were } 83888 \text { and } 372447 \text { for baseline measurement and, } 0 \text { and } 0 \text { for the } \\
\text { measurement made at the sixth month, respectively. } \\
\text { PROD: Paritaprevir-ritonavir-ombitasvir-dasabuvir combination, L/S: Ledipasvir-sofosbuvir combination, n: Number, SD: Standard deviation, HADS-A: Hospital Anxiety } \\
\text { and Depression scale-anxiety subscale, HADS-D: Hospital Anxiety and Depression scale-depression subscale }\end{array}$} \\
\hline
\end{tabular}




\begin{tabular}{|c|c|c|c|c|c|}
\hline \multirow{2}{*}{ Variable } & \multicolumn{2}{|l|}{ Baseline } & \multicolumn{3}{|l|}{ Month 1} \\
\hline & $n$ & $\%$ & \multicolumn{2}{|l|}{$n$} & $\%$ \\
\hline At risk for depression in L/S & 1 & 11.1 & \multicolumn{2}{|l|}{3} & 33.3 \\
\hline At risk for anxiety disorder in PROD & 5 & 62.5 & \multicolumn{2}{|l|}{4} & 50 \\
\hline At risk for depression $(n=17)$ & 1 & 5.9 & 4 & 23.5 & $p=0.250$ \\
\hline \multirow[t]{2}{*}{ At risk for anxiety disorder $(n=17)$} & 11 & 64.7 & 7 & 41.2 & $p=0.219$ \\
\hline & Mean & SD & Mean & SD & \\
\hline HADS-A for PROD & 6.88 & 3.8 & 7 & 3.66 & $\mathrm{~T}=-0.111, \mathrm{p}=0.915$ \\
\hline Viral load for PROD* (IU/mL) & 199007 & 250336.4 & 8 & 15.5 & $Z=-2.512, p=0.012$ \\
\hline Viral load for L/S (IU/mL) & 1752842.11 & 1611888.21 & 41 & 45.98 & $\mathrm{~T}=3.262, \mathrm{p}=0.011$ \\
\hline \multicolumn{6}{|c|}{$\begin{array}{l}\text { PROD group consists of } 8, \text { L/S group consists of } 9 \text { patients. } \\
\text { *Viral load for PROD had a skewed distribution. The median values and interquartile ranges were } 86013.5 \text { and } 364851 \text { for baseline measurement and, } 0 \text { and } 17 \text { for the } \\
\text { measurement made at the first month, respectively. } \\
\text { n: Number, L/S: Ledipasvir-sofosbuvir combination, SD: Standard deviation, PROD: Paritaprevir-ritonavir-ombitasvir-dasabuvir combination, HADS-A: Hospital Anxiety } \\
\text { and Depression scale-anxiety subscale, HADS-D: Hospital Anxiety and Depression scale-depression subscale }\end{array}$} \\
\hline
\end{tabular}

\begin{tabular}{|c|c|c|c|c|}
\hline \multicolumn{2}{|l|}{ Baseline } & \multicolumn{3}{|l|}{ Follow-up } \\
\hline$n$ & $\%$ & \multicolumn{2}{|l|}{$n$} & $\%$ \\
\hline 5 & 62.5 & \multicolumn{2}{|l|}{8} & 100 \\
\hline 0 & 0 & \multicolumn{2}{|l|}{1} & 10 \\
\hline 4 & 50 & \multicolumn{2}{|l|}{2} & 25 \\
\hline n & $\%$ & n & $\%$ & Statistics \\
\hline 13 & 72.2 & 17 & 94.4 & $p=0.125$ \\
\hline 0 & 0 & 3 & 16.7 & - \\
\hline 13.38 & 3.58 & 16.38 & 3.81 & $\mathrm{~T}=-3.310, \mathrm{p}=0.013$ \\
\hline 6.2 & 3.99 & 6.1 & 3.81 & $\mathrm{~T}=0.104, \mathrm{p}=0.919$ \\
\hline 6 & 3.16 & 5.88 & 3.8 & $\mathrm{~T}=0.092, \mathrm{p}=0.929$ \\
\hline 5.2 & 3.08 & 5.3 & 3.86 & $\mathrm{~T}=-0.118, \mathrm{p}=0.909$ \\
\hline 1645946.38 & 1719086.88 & 0 & 0 & $\mathrm{~T}=2.708, \mathrm{p}=0.030$ \\
\hline Median & IQR & Median & IQR & \\
\hline 4 & 5.75 & 5 & 8.5 & $Z=-1.364, p=0.172$ \\
\hline 86013.5 & 453062 & 0 & 0 & $Z=-2.803, p=0.005$ \\
\hline \multicolumn{5}{|c|}{$\begin{array}{l}\text { The lowest viral load achieved and the highest HAD-A, HAD-D and ASEX scores within six months were used for follow-up measurements. PROD group consists of } \\
\text { 10, L/S group consists of } 8 \text { patients. } \\
\text { n: Number, PROD: Paritaprevir-ritonavir-ombitasvir-dasabuvir combination, L/S: Ledipasvir-sofosbuvir combination, SD: Standard deviation, ASEX: Arizona Sexual } \\
\text { Experiences scale, HADS-A: Hospital Anxiety and Depression scale-anxiety subscale, HADS-D: Hospital Anxiety and Depression scale-depression subscale, IQR: } \\
\text { Interquartile range }\end{array}$} \\
\hline
\end{tabular}




\begin{tabular}{|c|c|c|c|c|c|}
\hline \multirow{2}{*}{ Variables } & \multicolumn{2}{|l|}{ Baseline } & \multicolumn{3}{|l|}{ Month 1} \\
\hline & Mean & SD & \multicolumn{2}{|l|}{ Mean } & SD \\
\hline ASEX for PROD & 14.88 & 4.58 & \multicolumn{2}{|l|}{15.63} & 3.58 \\
\hline ASEX for L/S & 14 & 4.16 & \multicolumn{2}{|l|}{15.25} & 3.69 \\
\hline HADS-A for PROD & 6.88 & 3.8 & \multicolumn{2}{|l|}{7} & 3.66 \\
\hline HADS-A for L/S & 6.5 & 2.89 & \multicolumn{2}{|l|}{3.25} & 1.71 \\
\hline HADS-D for PROD & 5.62 & 3.07 & \multicolumn{2}{|l|}{5.25} & 3.62 \\
\hline HADS-D for L/S & 5 & 3.92 & \multicolumn{2}{|l|}{4.5} & 3.32 \\
\hline \multirow[t]{2}{*}{ Viral load (IU/mL) for L/S } & 2343305.75 & 2145899.11 & \multicolumn{2}{|l|}{35.5} & 63.25 \\
\hline & Median & IQR & \multicolumn{2}{|l|}{ Median } & IQR \\
\hline \multirow[t]{2}{*}{ Viral load $(I U / m L)$ for PROD } & 86013.5 & 364 & \multicolumn{2}{|l|}{0} & 17 \\
\hline & $\mathbf{n}$ & $\%$ & \multicolumn{2}{|l|}{$\mathbf{n}$} & $\%$ \\
\hline Sexual dysfunction in PROD & 7 & 87.5 & \multicolumn{2}{|l|}{8} & 100 \\
\hline Sexual dysfunction in L/S & 3 & 75 & \multicolumn{2}{|l|}{4} & 100 \\
\hline At risk for depression in PROD & 0 & 0 & \multicolumn{2}{|l|}{1} & 12.5 \\
\hline At risk for depression in L/S & 0 & 0 & \multicolumn{2}{|l|}{0} & 0 \\
\hline At risk for anxiety disorder in PROD & 5 & 62.5 & \multicolumn{2}{|l|}{4} & 50 \\
\hline \multirow[t]{2}{*}{ At risk for anxiety disorder in L/S } & 2 & 50 & \multicolumn{2}{|l|}{0} & 0 \\
\hline & n & $\%$ & $\mathbf{n}$ & $\%$ & Statistics \\
\hline Sexual dysfunction ( $n=12)$ & 10 & 83.3 & 12 & 100 & - \\
\hline At risk for depression $(n=12)$ & 0 & 0 & 1 & 8.3 & - \\
\hline \multirow[t]{2}{*}{ At risk for anxiety disorder $(n=12)$} & 7 & 58.3 & 4 & 33.3 & $p=0.375$ \\
\hline & Mean & SD & Mean & SD & \\
\hline $\operatorname{ASEX}(n=12)$ & 14.58 & 4.27 & 15.5 & 3.45 & $\begin{array}{l}t=-1.201 \\
p=0.255\end{array}$ \\
\hline \multirow[t]{2}{*}{ HADS-A $(n=12)$} & 6.75 & 3.39 & 5.75 & 3.57 & $\begin{array}{l}T=1.049 \\
p=0.317\end{array}$ \\
\hline & Median & IQR & Median & IQR & \\
\hline HADS-D $(n=12)$ & 6 & 4.5 & 3.5 & 6.5 & $\begin{array}{l}Z=-0.360 \\
p=0.719\end{array}$ \\
\hline Viral load $(I U / m L)(n=12)$ & 356303 & 823297 & 0 & 20 & $\begin{array}{l}Z=-3.059, \\
p=0.002\end{array}$ \\
\hline \multicolumn{6}{|c|}{$\begin{array}{l}\text { PROD group consists of 8, L/S group consists of } 4 \text { patients. } \\
\text { SD: Standard deviation, ASEX: Arizona Sexual Experiences scale, PROD: Paritaprevir-ritonavir-ombitasvir-dasabuvir combination, L/S: Ledipasvir-sofosbuvir combination, } \\
\text { HADS-A: Hospital Anxiety and Depression scale-anxiety subscale, HADS-D: Hospital Anxiety and Depression scale-depression subscale, IQR: Interquartile range, n: } \\
\text { Number }\end{array}$} \\
\hline
\end{tabular}

Among 42, 18 patients completed the ASEX questionnaire at the baseline and at least in one of the following visits within six months. All the patients, who answered the questions of ASEX, filled in HADS also. Therefore, ASEX and HADS results of these 18 patients are given together in Table 3. Among these 18 patients, three (30\%) patients using PROD and four $(50 \%)$ patients using L/S were female. The average age of PROD group was $52.8 \pm 10.34$ and of $L / S$ group was $56.38 \pm 12.27$ years. There was no significant difference between baseline and following highest ASEX scores whereas there was a significant decrement in the viral load. Women had higher ASEX scores $(16.71 \pm 3.86)$ than men (12.18 \pm 3.37$)(p=0.018, t=2.631)$ at the baseline assessment, although there was no significant difference in terms of gender during the treatment period. No correlation was detected between
ASEX scores and age or viral load at the baseline assessment and during follow-up. Eight (61.5\%) patients with sexual dysfunction at the baseline assessment also had anxiety risk. During the followup period, all the patients with anxiety risk and depression risk also had sexual dysfunction.

Eight patients using PROD and four patients using L/S filled the ASEX both at the beginning of the treatment and at the first month. Among these 12 patients, three (37.5\%) patients using PROD and two (50\%) patients using L/S were female. The average age of PROD group was $54.63 \pm 10.11$ and of L/S group was $56 \pm 6.53$ years. Comparison of their baseline scores with the first-month scores for ASEX is given in Table 4. As there were only four patients in L/S group, statistical analysis for the comparison between baseline and first-month measurements is made for the whole 
group. All the patients with anxiety risk and depression risk at the first-month assessment had also sexual dysfunction. However, there was no correlation between ASEX scores and depression or anxiety scores neither at the baseline assessment nor at the firstmonth assessment.

\section{Discussion}

Health-care costs associated with hepatitis C (cirrhosis, cancer, transplantation) are increasing gradually over the years. Therefore, more effective, more tolerable, shorter and easier to use treatment regimens are needed. Today, DAAs replaced interferon and ribavirin treatment which had lower SVR with higher neuropsychiatric side effects $(20,28)$. In our study, SVR was achieved in $85.7 \%$ of patients with a rapid drop in viral load in the first month of treatment. Consistent with the literature, virological failure was rare.

Our results are in line with the studies reporting that DAA treatment did not affect anxiety and depression scores $(19,20)$. Although we used the highest depression or anxiety scores as following visit scores, we did not find any difference between baseline and following visit scores. Besides, consistent with the study of Gallach et al. (20) (2018), no significant differences were found in anxiety and depression scores when these variables were analyzed for age and gender. As depression was a leading side effect of interferon-containing treatments, most of the patients with psychiatric disorders could not get efficient treatments (10). DAAs seem to have a significant advantage over interferon-based treatments for psychiatric side effects. In a retrospective cohort study, it was found that Beck Depression Inventory scores improved with sofosbuvir-based treatment (29). DAAs are supposed to reduce extrahepatic manifestations such as fatigue and depression by reducing the systemic inflammation and immune activation secondary to HCV replication (30). However, in our study, we did not observe an improvement in depression or anxiety scores.

To our knowledge, there is no study which investigated the sexual effects of DAAs. In our study, we found that DAAs do not affect sexual scores of the patients. However, it is noteworthy that sexual dysfunction was found in around $75 \%$ of patients at the baseline assessment and around 95\% during the follow-up period. This high prevalence may be related to HCV infection itself. In a review of Karaivazoglou et al. (24), sexual dysfunction prevalence was reported to be $19.4-88 \%$ in men and $48.7-79 \%$ in women. In a study from Turkey, sexual dysfunction was found to be in $35 \%$ of 111 sexually active, drug naive patients with HCV (31). Consistent with most of the studies investigating sexual dysfunction in $\mathrm{HCV}$ patients, we found a greater sexual impairment in female patients at the baseline assessment. There are contradictory results about the association between sexual functioning and psychiatric variables in patients with HCV infection. In our study, we did not find any correlation between sexual functioning scores and anxiety or depression scores. On the other hand, it is important that all the patients with anxiety disorder risk or depression risk also had sexual dysfunction during the follow-up period. We can interpret this finding as depression and anxiety disorders may have an additional effect on sexual dysfunction in HCV-infected patients during DAA treatment. Use of antidepressants and some other medications are also related to sexual dysfunction (32). As we do not know other medications of the patients, we cannot make an ultimate comment about this finding. Further studies on the sexual effect of DAA are needed.

\section{Study Limitations}

Our primary limitation is the small sample size which was limited to a single site. Secondly, due to the retrospective design of the study, we cannot rule out the potential bias related to the missing data about the previous history of mental disorders and used psychiatric medications. Although the patients with depression or anxiety disorder risk were referred to a psychiatrist, they did not apply to the consulted psychiatrist. However, they might get medical advice from another source. As we do not have information about patients' use of psychotropic medication, we could not make a further analysis by omitting the patients who had psychiatric treatment. This shortage leads to a significant limitation. On the other hand, this is reflective of a real-life setting, as psychiatric patients keep their illness (including substance abuse) as a secret mostly, in Turkey. Additionally, treatment adherence of the patients was not asked. Besides, there may be a significant difference between the patients who completed the questionnaires and who did not, in terms of psychiatric status. Also, our findings are limited to PROD and L/S regimens, which may not be generalizable to other DAA agents. Another major limitation is using only self-report questionnaires. Further prospective studies with structured or semi-structured interview supplying comprehensive clinical assessment will improve our knowledge. Lastly, data about other factors which can be related to psychiatric conditions such as anemia, hypothyroidism or vitamin B12 deficiency are missing.

\section{Conclusion}

Studies focused on psychiatric adverse effects of DAAs in the real world are lacking and one strength of this study is providing findings from routine clinical practice. Our results reinforce the evidence that DAAs are well tolerated and characterized by having no effect on anxiety, depression levels or sexual health of the patients. Further prospective studies with larger patient samples are needed to enhance our knowledge about the safety of DAAs in the psychiatric area.

\section{Ethics}

Ethics Committee Approval: We have obtained approval for the study from the Infectious Diseases and Clinical Microbiology Department of Ege University.

Informed Consent: Patients gave consent to the use of their data.

Peer-review: Externally peer-reviewed.

\section{Authorship Contributions}

Concept: Ö.K.T., M.I.T., Design: Ö.K.T., D.A., H.P., T.Y., M.I.T., Ö.Ö.S., Data Collection or Processing: Ö.K.T., D.A., Analysis or Interpretation: Ö.K.T., D.A., H.P., T.Y., M.I.T., Ö.Ö.S., Literature Search: Ö.K.T., D.A., H.P., T.Y., M.I.T., Ö.Ö.S., Writing: Ö.K.T., D.A.

Conflict of Interest: The authors claim that they have no conflict of interest.

Financial Disclosure: The authors declared that this study received no financial support. 


\section{References}

1. Polaris Observatory HCV Collaborators. Global prevalence and genotype distribution of hepatitis C virus infection in 2015: a modelling study. Lancet Gastroenterol Hepatol. 2017;2:161-176.

2. European Union HCV Collaborators. Hepatitis $C$ virus prevalence and level of intervention required to achieve the WHO targets for elimination in the European Union by 2030: a modelling study. Lancet Gastroenterol Hepatol. 2017;2:325-336.

3. Tozun N, Ozdogan O, Cakaloglu Y, Idilman R, Karasu Z, Akarca U, Kaymakoglu S, Ergonul O. Seroprevalence of hepatitis B and C virus infections and risk factors in Turkey: a fieldwork TURHEP study. Clin Microbiol Infect. 2015;21:1020-1026.

4. Tiryaki Y, Cetin Duran A, Ozcolpan OO. Distribution of hepatitis C virus genotypes in Aydın province. Viral Hepat J. 2018;24:70-74.

5. Abacioglu YH, Davidson F, Tuncer S, Yap PL, Ustacelebi S, Yulug $\mathrm{N}$, Simmonds $\mathrm{P}$. The distribution of hepatitis $\mathrm{C}$ virus genotypes in Turkish patients. J Viral Hepat. 1995;2:297-301.

6. Altuğlu I, Sertöz R, Aksoy A, Gürsel D, Tüzüner U, Günşar F. Possible transmission risks and genotype distribution of hepatitis $\mathrm{C}$ virus infection in Western Turkey. Turk J Gastroenterol. 2013;24:349355

7. Iba Yilmaz S, Erol S, Özbeks A, Parlak M. Distribution of viral genotypes and extrahepatic manifestations in patients with chronic hepatitis C in Eastern Turkey. Turk J Med Sci. 2015;45:7075.

8. Jakobsen JC, Nielsen EE, Feinberg J, Katakam KK, Fobian K, Hauser G, Poropat G, Djurisic S, Weiss KH, Bjelakovic M, Bjelakovic G, Klingenberg SL, Liu JP, Nikolova D, Koretz RL, Gluud C. Directacting antivirals for chronic hepatitis C. Cochrane Database Syst Rev. 2017;6:CD012143.

9. Afdhal N, Zeuzem S, Kwo P, Chojkier M, Gitlin N, Puoti M, RomeroGomez M, Zarski JP, Agarwal K, Buggisch P, Foster GR, Brau N, But $M$, Jacobson IM, Subramanian GM, Ding $X$, Mo H, Yang JC, Pang PS, Symonds WT, McHutchison JG, Muir AJ, Mangia A, Marcellin $\mathrm{P}$, Investigators ION. Ledipasvir and sofosbuvir for untreated HCV genotype 1 infection. N Engl J Med. 2014;370:1889-1898.

10. Rowan PJ, Bhulani N. Psychosocial assessment and monitoring in the new era of non-interferon-alpha hepatitis $\mathrm{C}$ virus treatments. World J Hepatol. 2015;7:2209-2213.

11. Karabay $O$, Öğütlü $A$, Güçlü E. Hepatit $C$ tedavisinde 2016 sağlık uygulama tebliğinin getirdiği yenilikler. Online Türk Sağlık Bilimler Dergisi. 2016;1:23-29

12. Leutscher $P D$, Lagging $M$, Buhl MR, Pedersen C, Norkrans G, Langeland N, Morch K, Farkkila M, Hjerrild S, Hellstrand K, Bech P. Evaluation of depression as a risk factor for treatment failure in chronic hepatitis C. Hepatology. 2010;52:430-435.

13. Lotrich FE. Psychiatric clearance for patients started on interferonalpha-based therapies. Am J Psychiatry. 2013;170:592-597.

14. Marcellin P, Lau GK, Zeuzem S, Heathcote EJ, Pockros PJ, Reddy KR, Piratvisuth T, Farci P, Chow WC, Jia JD, Paik W, Wintfeld N, Pluck N. Comparing the safety, tolerability and quality of life in patients with chronic hepatitis $\mathrm{B}$ vs chronic hepatitis $\mathrm{C}$ treated with peginterferon alpha-2a. Liver Int. 2008;28:477-485.

15. Wedemeyer $H$, Craxi $A$, Zuckerman $E$, Dieterich $D$, Flisiak $R$, Roberts SK, Pangerl A, Zhang Z, Martinez M, Bao Y, Calleja JL. Real-world effectiveness of ombitasvir/paritaprevir/ritonavir+/dasabuvir+/-ribavirin in patients with hepatitis $C$ virus genotype 1 or 4 infection: A meta-analysis. J Viral Hepat. 2017;24:936-943.

16. Kowdley $K V$, Gordon $S C$, Reddy $K R$, Rossaro $L$, Bernstein $D E$ Lawitz E, Shiffman ML, Schiff E, Ghalib R, Ryan M, Rustgi $V_{\text {, }}$ Chojkier M, Herring R, Di Bisceglie AM, Pockros PJ, Subramanian GM, An D, Svarovskaia E, Hyland RH, Pang PS, Symonds WT, McHutchison JG, Muir AJ, Pound D, Fried MW; ION-3. Ledipasvir and sofosbuvir for 8 or 12 weeks for chronic HCV without cirrhosis. N Engl J Med. 2014;370:1879-1888.

17. Ferenci P, Bernstein D, Lalezari J, Cohen D, Luo Y, Cooper C, Tam E, Marinho RT, Tsai N, Nyberg A, Box TD, Younes Z, Enayati $P$, Green S, Baruch Y, Bhandari BR, Caruntu FA, Sepe T, Chulanov V, Janczewska E, Rizzardini G, Gervain J, Planas R, Moreno C, Hassanein T, Xie W, King M, Podsadecki T, Reddy KR; PEARL-III Study; PEARL-IV Study. ABT-450/r-ombitasvir and dasabuvir with or without ribavirin for HCV. N Engl J Med. 2014;370:1983-1992.

18. Cacoub $P$, Bourliere $M$, Asselah $T$, De Ledinghen $V$, Mathurin P, Hezode C, Henry L, Stepanova M, Younossi ZM. French patients with hepatitis $\mathrm{C}$ treated with direct-acting antiviral combinations: The effect on patient-reported outcomes. Value Health. 2018;21:1218-1225.

19. Sundberg I, Lannergard A, Ramklint M, Cunningham JL. Directacting antiviral treatment in real world patients with hepatitis C not associated with psychiatric side effects: a prospective observational study. BMC Psychiatry. 2018;18:157.

20. Gallach M, Vergara M, da Costa JP, Miquel M, Casas M, SanchezDelgado J, Dalmau B, Rudi N, Parra I, Monllor T, Sanchez-Lloansi M, Dosal A, Valero O, Calvet X. Impact of treatment with directacting antivirals on anxiety and depression in chronic hepatitis $\mathrm{C}$. PLoS One. 2018;13:e0208112.

21. Zigmond AS, Snaith RP. The hospital anxiety and depression scale. Acta Psychiatr Scand. 1983;67:361-370.

22. Sackey B, Shults JG, Moore TA, Rogers R, Mehvar M, King JG. Evaluating psychiatric outcomes associated with direct-acting antiviral treatment in veterans with hepatitis $\mathrm{C}$ infection. Ment Health Clin. 2018;8:116-121.

23. Lenz DU, Crutcher EL, Greene EM. Sexual Dysfunction in a Patient taking ledipasvir/sofosbuvir for the treatment of hepatitis C: A Case Report. J Pharm Pract. 2017:897190017744421.

24. Karaivazoglou K, Tsermpini EE, Assimakopoulos K, Triantos C. Sexual functioning in patients with chronic hepatitis C: a systematic review. Eur J Gastroenterol Hepatol. 2017;29:11971205.

25. McGahuey CA, Gelenberg AJ, Laukes CA, Moreno FA, Delgado $\mathrm{PL}$, McKnight KM, Manber R. The Arizona Sexual Experience scale (ASEX): reliability and validity. J Sex Marital Ther. 2000;26:2540.

26. Aydemir Ö, Güvenir T, Küey L, Kültür S. Hastane anksiyete depresyon ölçeği Türkçe formunun geçerlilik ve güvenilirliği. Türk Psikiyatri Dergisi. 1997;8:280-287.

27. Soykan A. The reliability and validity of Arizona sexual experiences scale in Turkish ESRD patients undergoing hemodialysis. Int J Impot Res. 2004;16:531-534.

28. Sockalingam S, Sheehan K, Feld JJ, Shah H. Psychiatric care during hepatitis $C$ treatment: the changing role of psychiatrists in the era of direct-acting antivirals. Am J Psychiatry. 2015;172:512 516 .

29. Tang LS, Masur J, Sims Z, Nelson A, Osinusi A, Kohli A, Kattakuzhy S, Polis M, Kottilil S. Safe and effective sofosbuvir-based therapy in patients with mental health disease on hepatitis $C$ virus treatment. World J Hepatol. 2016;8:1318-1326.

30. Salmon D, Mondelli MU, Maticic M, Arends JE; ESCMID study group for viral hepatitis. The benefits of hepatitis C virus cure: Every rose has thorns. J Viral Hepat. 2018;25:320-328.

31. Soykan A, Boztas $H$, Idilman $R$, Ozel ET, Tüzün $A E$, Ozden $A$ Ozden A, Kumbasar H. Sexual dysfunctions in HCV patients and its correlations with psychological and biological variables. Int J Impot Res. 2005;17:175-179.

32. Fabregas BC, Moura AS, Avila RE, Faria MN, Carmo RA, Teixeira AL. Sexual dysfunction and dissatisfaction in chronic hepatitis $C$ patients. Rev Soc Bras Med Trop. 2014;47:564-572. 